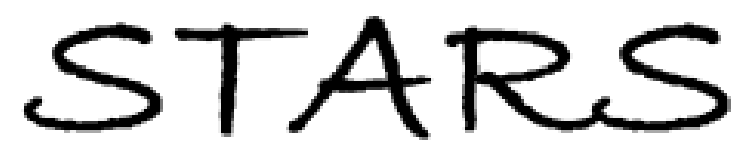

University of Central Florida

STARS

Faculty Bibliography 2010s

Faculty Bibliography

$1-1-2010$

\title{
The Direct and Indirect Effects of Advertising Spending on Firm Value
}

Amit Joshi

University of Central Florida

Dominique M. Hanssens

Find similar works at: https://stars.library.ucf.edu/facultybib2010 University of Central Florida Libraries http://library.ucf.edu

This Article is brought to you for free and open access by the Faculty Bibliography at STARS. It has been accepted for inclusion in Faculty Bibliography 2010 s by an authorized administrator of STARS. For more information, please contact STARS@ucf.edu.

\section{Recommended Citation}

Joshi, Amit and Hanssens, Dominique M., "The Direct and Indirect Effects of Advertising Spending on Firm Value" (2010). Faculty Bibliography 2010s. 315.

https://stars.library.ucf.edu/facultybib2010/315

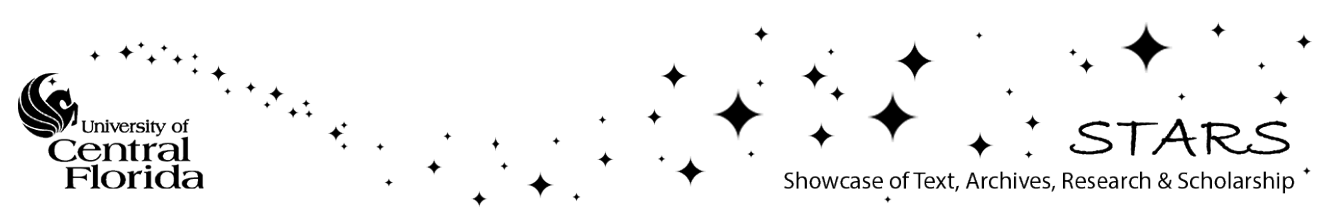




\section{The Direct and Indirect Effects of Advertising Spending on Firm Value}

Marketing decision makers are increasingly aware of the importance of shareholder value maximization, which calls for an evaluation of the long-term effects of their actions on product-market response and investor response. However, the marketing literature to date has focused on the sales or profit response of marketing actions, and the goals of marketing have traditionally been formulated from a customer perspective. Recently, there have been a few studies of the long-term investor response to marketing actions. The current research investigates one important aspect of this impact, the long-term relationship between advertising spending and market capitalization. The authors hypothesize that advertising can have a direct effect on valuation (i.e., an effect beyond its indirect effect through sales revenue and profit response). The empirical results across two industries provide support for the hypothesis that advertising spending has a positive, long-term impact on own firms' market capitalization and may have a negative impact on the valuation of a competitor of comparable size. The authors quantify the magnitude of this investor response effect for and discuss its implications for further research.

Keywords: advertising, stock market valuation, marketing-finance interface, stock return modeling, optimal advertising spending, competitive response

$\mathbf{T}$ he shareholder value principle advocates that a business should be run to maximize the return on shareholders' investment, and shareholder value analysis (SVA) is fast becoming a new standard for judging managerial action. In this changing scenario, in which short-term accounting profits are giving way to SVA, it is advisable that all investments made by managers be viewed in the context of shareholder returns. Thus, every investment, be it in the area of operations, human resources, or marketing, may now need to be justified from the SVA perspective. The common yardstick that most investors use in this context is the share price, or more generally, the wealth created by a firm is measured by its market capitalization.

This evolution presents a great opportunity for marketing. Indeed, by focusing on short-term profits at the expense of intangible assets, traditional accounting may marginalize marketing. In contrast, SVA takes a long-term perspective and encourages managers to make profitable investments. To capitalize on this opportunity, marketing will need to justify its budgets in shareholder value terms. This is a difficult task because the goals of marketing are traditionally formulated in customer attitude or sales performance terms. Furthermore, marketing may affect business performance in both tangible and intangible ways. Consequently, marketing budgets are vulnerable, especially advertising spending

Amit Joshi is an Assistant Professor of Marketing, Department of Marketing, College of Business Administration, University of Central Florida (e-mail: ajoshi@bus.ucf.edu). Dominique M. Hanssens is Bud Knapp Professor of Marketing, Anderson School of Management, University of California, Los Angeles (e-mail: dominique.hanssens@ anderson.ucla.edu). The authors acknowledge the financial support of the Marketing Science Institute. The first author also thanks all the members of his doctoral committee for helpful comments.
(Lodish and Mela 2007). Although the effects of advertising on sales have been researched in depth (for a review, see, e.g., Hanssens, Parsons, and Schultz 2001), there has been little effort to study the direct impact of advertising on stock price (Figure 1). Thus, the primary motivation of this article is to investigate the impact of advertising spending on firm value beyond its effect on sales revenues and profits.

\section{Tangible and Intangible Effects}

Firm value has been classified as tangible and intangible value (Simon and Sullivan 1993). From a marketing perspective, tangible assets include sales and profits, and the impact of marketing instruments on these has been well documented for both the short run (e.g., Lodish et al. 1995) and the long run (e.g., Nijs et al. 2001; Simester et al. 2009). In modern economies, however, a large part of firm value may reflect its intangible assets, such as brand equity (Chan, Lakonishok, and Sougiannis 2001). Because these intangible assets are not required to be reported in firms' financial statements under the generally accepted U.S. accounting principles, their valuation is further complicated. At the same time, research indicates that nonfinancial indicators of investments in "intangible" assets, such as customer satisfaction, may be better predictors of future financial performance than historical accounting measures and should supplement financial measures in internal accounting systems (Ittner and Larcker 1998).

Intangible assets can be classified as (1) market-specific factors, such as regulations that lead to imperfect competition; (2) firm-specific factors, such as research-and-development (R\&D) expenditures and patents; and (3) brand equity (Simon and Sullivan 1993). To date, the finance literature and the policy literature have established a relationship 


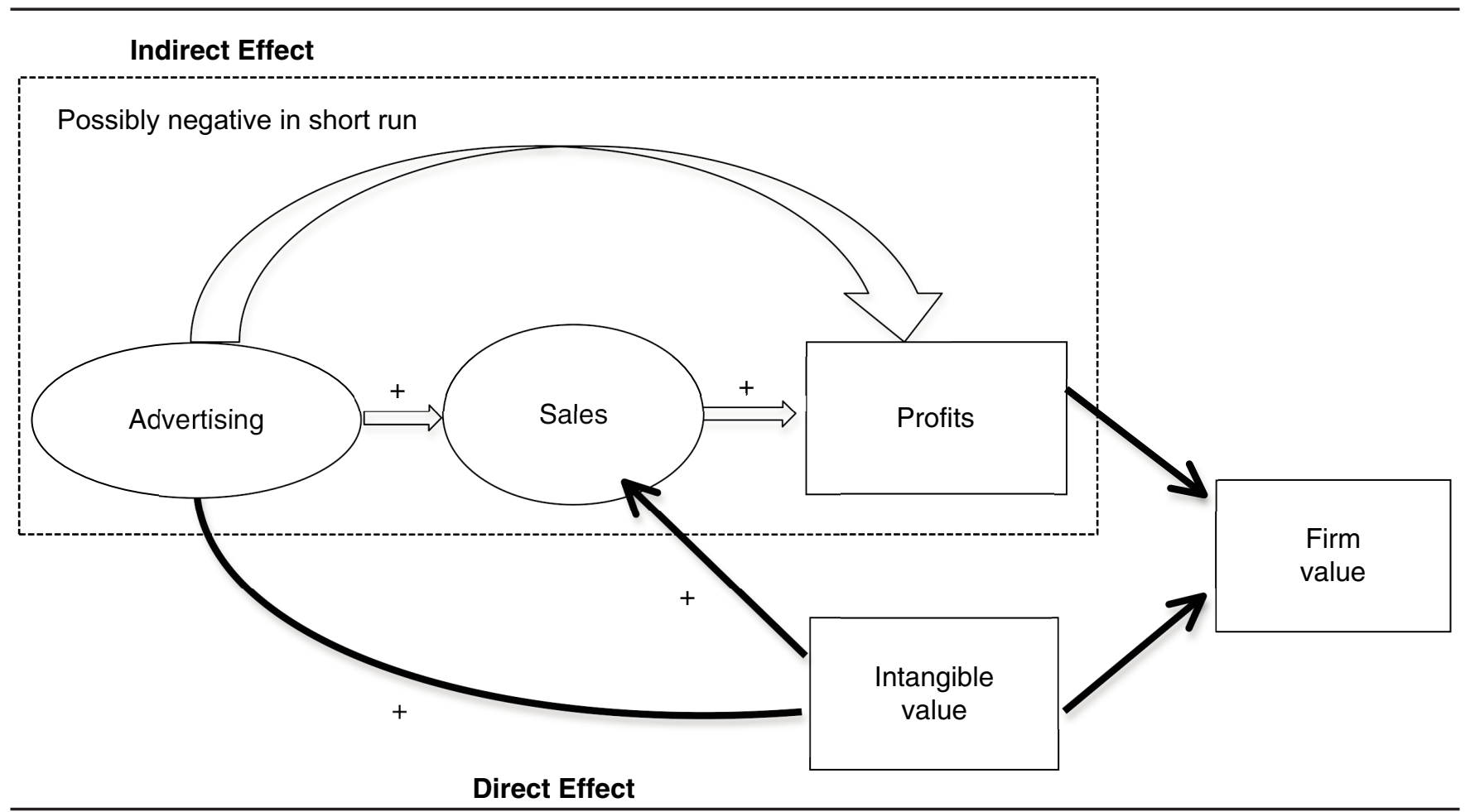

between firm value and market-specific factors (e.g., Chhaochharia and Grinstein 2007; Lamdin 1999), which is beyond the scope of this article.

Firm-specific factors have been shown to have a positive impact on firm value. Such factors include R\&D expenditures (Chan, Lakonishok, and Sougiannis 2001); discretionary expenditures, such as R\&D and advertising (Erickson and Jacobson 1992); and innovation (Pauwels et al. 2004).

A few marketing articles address the link between brand-related intangible assets and firm value. These include studies on the stock market reaction to a change in a company's name (Horsky and Swyngedouw 1987), to new product announcements (Chaney, Devinney, and Winer 1991), to perceived quality (Aaker and Jacobson 1994), to brand extensions (Lane and Jacobson 1995), and to brand attitude (Aaker and Jacobson 2001). Research has also established that the impact of marketing variables on brandrelated intangible assets may be moderated by the type of branding strategy the firm adopts (Joshi 2005; Rao, Agarwal, and Dahlhoff 2004). Recent work in marketing has also established a strong relationship between customer satisfaction and firm value (Fornell et al. 2006). On the basis of the results in these studies, we may expect advertising to have an indirect impact on firm value (through an increase in sales and profits), as well as a direct effect (by building brand-related intangible assets). Thus, our research relates firm-specific factors and brand equity to firm value.

\section{Capital Market Efficiency}

Most of the aforementioned studies use the "event study" methodology, in which stock prices/abnormal stock returns are tracked around a time window surrounding the focal events. As such, these studies address the long-term impact of the change on stock prices only if markets are (nearly) perfectly efficient, under the efficient capital markets hypothesis. The efficient capital markets hypothesis (Fama 1970) states that the current stock price contains all available information about the future expected profits of a firm. Future profit expectations are the only driver of stock price, and thus stock prices may be modeled as a random walk, in which changes in these expectations are incorporated immediately and fully. However, more recent work in finance, marketing, and strategy indicates that the efficient capital markets hypothesis may not always hold (Fornell et al. 2006; Merton 1987). In particular, researchers have questioned the appropriateness of the assumptions of immediate dissemination of all available information. Kothari (2001, p. 208) acknowledges that there is increasing evidence that "markets may be informationally inefficient" and "prices might take years before they fully reflect available information." In marketing, Pauwels and colleagues (2004) demonstrate that marketing activities, such as new product introductions, contain information that takes several weeks to be fully incorporated in firm value. This finding motivates the use of long-term or persistence models instead of event windows to study the impact of intangible assets on firm value.

In conclusion, although there is some evidence of a possible relationship between marketing activities and financial performance, no studies have directly examined the longterm effects of advertising expenditures on firm value. Furthermore, to the best of our knowledge, only one study (Fosfuri and Giarratana 2009) has investigated the impact of 
competitive advertising on focal firm stock price. If the efficient capital markets hypothesis holds, we would find no long-term effects because the impact of own and competitor advertising would be fully contained in the next period's stock price. However, some studies suggest otherwise, indicating that there can be an effect buildup beyond the short run. In this study, we use persistence or vector autoregressive (VAR) modeling (Dekimpe and Hanssens 1995b) to study the long-term effect of advertising expenditures on stock return. Vector autoregressive models enable us to investigate long-term investor response to advertising or other firm actions, while recognizing the endogeneity of these discretionary expenditures (e.g., advertising, R\&D) with profits and, thus, firm value. We also model the impact of competitive advertising expenditures on firm value. The use of VAR modeling, though only recently introduced in the marketing-finance literature, has been shown to be successful in modeling stock return (e.g., Luo 2009). In addition, we illustrate the economic impact of our results by simulating changes in market capitalization under different advertising spending scenarios with and without competitive reaction. We begin with the development of our hypotheses.

\section{Hypothesis Development}

The central hypothesis we test in this research is as follows:

$\mathrm{H}_{1}$ : Advertising has a positive long-term effect on stock return beyond its impact through sales revenues and profits.

The sources of advertising's impact on firm value are spillover and signaling, which we now discuss in detail.

\section{Spillover}

Advertising attempts to differentiate a firm's products from those of its competitors, thus creating brand equity for its products (Aaker 1991). We hypothesize that this equity, which is created through marketing activity and is ostensibly directed at customers and prospects, can spill over into investment behavior as well. For example, Frieder and Subrahmanyam (2005) find that investors favor stocks with strong brand names, even though these powerful brands do not generate superior short-term returns. They acknowledge (p. 82) that "individual investors may believe, correctly or not, that they can expect greater appreciation potential in the stock of companies whose products are recognized brand names." Overall, their results indicate that brand awareness and perceived brand quality in consumer products may spill over to the demand for stocks of their companies.

Research in behavioral decision theory provides support for the spillover effect. Heath and Tversky (1990) find that people prefer to bet in areas in which they feel confident and have knowledge about the uncertainties involved, compared with more ambiguous areas. Such a preference can carry over to investment decisions in that investors may prefer to hold branded stocks for which the flow of public information is higher. Further support is provided by Huberman (2001), who finds that investors often invest in the familiar while ignoring principles of portfolio theory. Insofar as advertising generates familiarity, we would expect that heavily advertised stocks are more attractive investment options.

\section{Signaling}

Advertising can also act as a signal of financial well-being or competitive viability of a firm. Numerous signaling mechanisms can influence investor behavior. Among the more recent research on this effect is Mathur and Mathur's (2000) work on the stock market's reaction to the announcement of "green" marketing strategies and Mathur, Mathur, and Rangan's (1997) work on the celebrity endorsement effect on firm valuation. The latter study finds that Michael Jordan's much-publicized return to the National Basketball Association resulted in an average increase in the marketadjusted values of his client firms of almost $2 \%$, or more than $\$ 1$ billion in market capitalization. In the motion picture industry, prelaunch advertising has been shown to increase stock prices and possibly create unrealistic expectations about a movie's performance, leading to postlaunch price corrections (Joshi and Hanssens 2009). Thus, advertising in various forms may serve as a signal of future earnings potential. In a study of the impact of environmental friendliness on firm value, Gifford (1997) finds that merely establishing a proenvironment practice is insufficient and that firms must advertise this to the investment community before it translates into increased financial returns. In this case, advertising provides information that does not necessarily affect the sales of the firm but has a direct effect on its stock price. Similarly, Mizik and Jacobson (2003) find that value creation (e.g., R\&D) alone does not enhance firm value and that it is necessary to have value appropriation (e.g., through advertising) for that to occur. Thus, although R\&D can create value through innovation, the firm can only fully benefit after the innovations are commercialized. Evidence of this is provided by Pauwels and colleagues (2004), who find that new product introductions affect both the top and the bottom line of firms, and by Sood and Tellis (2009), who find that even announcements indirectly related to innovation (e.g., funding, expansions, and preannouncements of new product projects) affect firm value.

Further evidence in favor of signaling effects is provided by Chauvin and Hirschey (1993, p. 128), who report that "data on advertising and R\&D spending appear to help investors form expectations concerning the size and variability of future cash flows." Although their analysis is restricted to short-term effects, the results point in the direction of a positive impact of advertising on firm value. More recently, the signaling effect of advertising was examined in the accounting and auditing literature (Simpson 2008). Simpson (2008) finds an impact of advertising expenditures on both own and competitive firm market values and also reports that firms voluntarily disclose their own advertising expenditures only if past disclosures led to an increase in own firm value. This research is notable in that it demonstrates a competitive aspect of the advertising signaling effect (i.e., firms in the same space as the advertiser may suffer a decline in their valuation). We incorporate this competitive aspect of advertising in our empirical analysis. 


\section{Direct and Indirect Effects}

Though not the primary focus of our research, our model needs to account for the effects of sales revenue and $R \& D$, along with firm profitability, on valuation. Extensive prior research on the effects of advertising on sales provides an empirical generalization that the short-term elasticity on own brand sales is positive but low and that advertising will have a long-term effect only if the short-term effect is significant (Lodish et al. 1995). Thus, advertising can affect firm value indirectly through an increase in sales revenues. Furthermore, research in marketing and strategy has also demonstrated the positive impact of new product introductions on sales (Nijs et al. 2001). Because product innovation requires $R \& D$, it has also been established that $R \& D$ expenditures have a positive impact on the market value of the firm (Cockburn and Griliches 1988).

Although the foregoing studies provide evidence that advertising may have a positive effect on valuation, we do not know its possible magnitude. In the short run, advertising will likely work through the indirect, tangible routethat is, increasing valuation through lifting sales and profits, which are known to be incorporated immediately. The direct effect may or may not take longer to materialize, depending on how quickly investors update their perceptions of the firm's differentiation as a result of the advertising. Its magnitude is expected to be smaller because cash flow effects have already been taken into account. Overall, because both spillover and signaling are positive forces, we expect the net investor impact of advertising to be nonnegative.

\section{Model}

\section{Model Specification}

The relationship between profits and valuation has been examined extensively in the finance literature. However, the direct relationship between advertising and valuation is more ambiguous. Only effective advertising can generate sales profitably, and not all advertising is effective. Furthermore, even effective advertising can reduce profit in the short run because the advertising budget is a direct expenditure against current revenue. Finally, in accordance with our hypothesis, there could be a branding effect of advertising by itself, beyond the additional cash flows generated by an ad campaign, which could affect the intangible assets of a firm. Thus, we need a systems model rather than a singleequation approach to study our hypothesis.

In addition, the workings of advertising need to be studied in the long run if its impact lasts well beyond the accounting period in which the advertising is spent. In so doing, we must recognize that firm value, sales, profits, and advertising expenditures can all have feedback effects on one another. For example, a higher profit in one period may lead to increased advertising budgets, which in turn may boost sales and future profits. To disentangle these effects, we use a dynamic systems representation, in particular a VAR model in which the advertising and performance variables are jointly endogenous.

From a finance perspective, we use multiple measures of stock return to test our hypothesis (Jacobson and Mizik
2009). Specifically, we use both market-to-book ratio (MBR) and matched firm returns (MFRs) as our dependent variable, and we compare the results. While the MBR is common in marketing-finance applications, the MFR approach has not received much attention. We discuss the MFR metric in greater detail subsequently.

The method of matching firms to adjust for the factors in the Fama-French three-factor model (Fama and French 1992) was introduced by Barber and Lyon (1997). The basic principle is to use firm matching so that industry risk, firm size (large versus small), and equity (high versus low MBR) effects are adjusted for in the calculation of the dependent variable itself. Barber and Lyon test this metric against several other stock return metrics from previous finance literature and conclude that it is the superior metric under most circumstances.

We calculate the metric as follows:

1. We obtain monthly returns, firm size, Standard Industrial Classification (SIC), and MBR value for the firms in our study using the Center for Research in Security Prices (CRSP) database.

2. We order firms within the same four-digit SIC code by size and MBR. We then match each firm for each month with a control firm in the same four-digit SIC. The firm that matches best with the focal firm is then selected as the matching firm.

3. In some cases, matched firms need to be identified from outside the four-digit SIC of the focal firm for the following reasons:

a. It is possible that there is no matching firm within $\pm 30 \%$ of the size of the focal firm (which is the range recommended in Barber and Lyon [1997]).

b. It is possible that the matching firm is another focal firm. For example, Hewlett-Packard (HP) could be a matching firm for IBM. However, this implies that IBM would also be the matching firm for HP, which would lead to pairs of values of equal magnitude but opposite sign. ${ }^{1}$

c. Finally, data could be missing from the CRSP database. In all these cases, a matching firm is identified from a coarser SIC level (three-digit SIC or two-digit SIC). ${ }^{2}$ When a matching firm is determined, the difference between the stock return for the focal firm and the matched firm is the MFR for the focal firm for that period.

4. The difference between the returns of the focal firm and matched firm are the MFRs.

Although MFR is a powerful metric, it is not without limitations. The results are dependent on finding the appropriate matching firm. Consequently, we validate our results using a MBR measure in addition to MFR.

Apart from valuation, profits, sales, and advertising expenditures, we also include an equation for R\&D expenditures. Previous studies have concluded that stock prices react favorably to $R \& D$ spending, while $R \& D$ expenditures may themselves be dependent on firm performance.

In addition to the aforementioned variables, research has also identified innovation as a potential driver of stock

${ }^{1}$ Note that collinear pairs are not a concern for firm-by-firm modeling, as we do. However, it will affect the pooled model.

2Alternatively, it may also be beneficial (even necessary) to identify a matching firm from a completely different SIC classification, which may also be assigned to the focal firm as a secondary classification. 
prices. Therefore, we also include an innovation variable as an exogenous variable in our model. Recent research has indicated that investors react positively to firm innovation and even to announcements about possible future innovation (Sood and Tellis 2009). Innovation by competitors has been shown to affect a focal firm both directly and through the increased advertising that typically accompanies new product launches (Fosfuri and Giarratana 2009). Indeed, Srinivasan and colleagues (2009) demonstrate not only that firms spend more on advertising new products but also that the effectiveness of that advertising is enhanced for truly path-breaking products. Following these studies, we treat the innovation variable as exogenous.

Because the variables advertising (A), sales revenue (R), profit (P), and R\&D expenditures (RD) can all be jointly endogenous with stock return (MFR), a VAR model in differences with $\mathrm{J}$ lagged periods is as follows: ${ }^{3}$

(1)

$$
\left[\begin{array}{l}
\Delta \mathrm{MFR}_{\mathrm{t}} \\
\Delta \mathrm{R}_{\mathrm{t}} \\
\Delta \mathrm{P}_{\mathrm{t}} \\
\Delta \mathrm{A}_{\mathrm{t}} \\
\Delta \mathrm{RD}_{\mathrm{t}}
\end{array}\right]=\left[\begin{array}{l}
\gamma_{\mathrm{MFR}, \mathrm{t}} \\
\gamma_{\mathrm{R}, \mathrm{t}} \\
\gamma_{\mathrm{P}, \mathrm{t}} \\
\gamma_{\mathrm{A}, \mathrm{t}} \\
\gamma_{\mathrm{RD}, \mathrm{t}}
\end{array}\right]
$$

$$
+\sum_{J=1}^{J}\left[\begin{array}{lllll}
\pi_{11}^{\mathrm{j}} & \pi_{12}^{\mathrm{j}} & \pi_{13}^{\mathrm{j}} & \pi_{14}^{\mathrm{j}} & \pi_{15}^{\mathrm{j}} \\
\pi_{21}^{\mathrm{j}} & \pi_{22}^{\mathrm{j}} & \pi_{23}^{\mathrm{j}} & \pi_{24}^{\mathrm{j}} & \pi_{25}^{\mathrm{j}} \\
\pi_{31}^{\mathrm{j}} & \pi_{32}^{\mathrm{j}} & \pi_{33}^{\mathrm{j}} & \pi_{34}^{\mathrm{j}} & \pi_{35}^{\mathrm{j}} \\
\pi_{41}^{\mathrm{j}} & \pi_{42}^{\mathrm{j}} & \pi_{43}^{\mathrm{j}} & \pi_{44}^{\mathrm{j}} & \pi_{45}^{\mathrm{j}} \\
\pi_{51}^{\mathrm{j}} & \pi_{52}^{\mathrm{j}} & \pi_{53}^{\mathrm{j}} & \pi_{54}^{\mathrm{j}} & \pi_{55}^{\mathrm{j}}
\end{array}\right]\left[\begin{array}{l}
\Delta \mathrm{MFR}_{\mathrm{t}-\mathrm{j}} \\
\Delta \mathrm{R}_{\mathrm{t}-\mathrm{j}} \\
\Delta \mathrm{P}_{\mathrm{t}-\mathrm{j}} \\
\Delta \mathrm{A}_{\mathrm{t}-\mathrm{j}} \\
\Delta \mathrm{RD}_{\mathrm{t}-\mathrm{j}}
\end{array}\right]+\left[\begin{array}{l}
\mathrm{u}_{\mathrm{MFR}, \mathrm{t}} \\
\mathrm{u}_{\mathrm{R}, \mathrm{t}} \\
\mathrm{u}_{\mathrm{P}, \mathrm{t}} \\
\mathrm{u}_{\mathrm{A}, \mathrm{t}} \\
\mathrm{u}_{\mathrm{RD}, \mathrm{t}}
\end{array}\right] .
$$

${ }^{3}$ For the sake of brevity, we use MFR to represent both our stock return methods (MBR and MFR). In a time-series context, we know from the finance literature that MFR will have a randomwalk component, so the VAR models will be specified in differences $(\Delta)$ or a mixture of levels and differences. In what follows, we assume the former. For ease of exposition, we do not show exogenous variables.
This representation combines market response and decision response effects. Consider the partitioned coefficient matrix for the first lag in this model:

$$
\begin{array}{lll:ll}
\pi_{11}^{1} & \pi_{12}^{1} & \pi_{13}^{1} & \pi_{14}^{1} & \pi_{15}^{1} \\
\pi_{21}^{1} & \pi_{22}^{1} & \pi_{23}^{1} & \pi_{24}^{1} & \pi_{25}^{1} \\
\pi_{31}^{1} & \pi_{32}^{1} & \pi_{33}^{1} & \pi_{34}^{1} & \pi_{35}^{1} \\
\hdashline \pi_{41}^{1} & \pi_{42}^{1} & \pi_{34}^{1} & \pi_{44}^{1} & \pi_{45}^{1} \\
\pi_{51}^{1} & \pi_{52}^{1} & \pi_{35}^{1} & \pi_{45}^{1} & \pi_{55}^{1}
\end{array}
$$

In this matrix, the top-left partition represents the market response coefficients for stock return (momentum), sales revenue, and profit, respectively. The $(3 \times 2)$ matrix in the top-right corner shows the direct response effects of advertising and R\&D on firm value, revenue, and profit. The bottom-right partition captures firm-specific decision rules between advertising and R\&D spending. Finally, the bottomleft matrix measures performance feedback effects. For example, an increase in next-period advertising spending due to higher sales revenue would be captured by the coefficient $\pi_{42}^{1}$. In the systems of equations in Equation 1, $\left[\mathrm{u}_{\mathrm{MFR}}, \mathrm{u}_{\mathrm{R}}, \mathrm{u}_{\mathrm{P}}, \mathrm{u}_{\mathrm{A}}, \mathrm{u}_{\mathrm{RD}}\right]^{\prime} \sim \mathrm{N}\left(0, \Sigma_{\mathrm{u}}\right)$, and the order of the system, $\mathrm{J}$, is determined by minimizing Schwartz's Bayesian information criterion (BIC). A single equation in this system would be as follows (for MFR, assuming a lag length of one):

$$
\begin{aligned}
\Delta \mathrm{MFR}_{\mathrm{t}} & =\gamma_{\mathrm{MFR}, \mathrm{t}}+\pi_{11}^{1} \Delta \mathrm{MFR}_{\mathrm{t}-1} \\
& +\pi_{11}^{1} \Delta \mathrm{R}_{\mathrm{t}-1}+\pi_{11}^{1} \Delta \mathrm{P}_{\mathrm{t}-1}+\pi_{11}^{1} \Delta \mathrm{A}_{\mathrm{t}-1} \\
& +\pi_{11}^{1} \Delta \mathrm{RD}_{\mathrm{t}-1}+\alpha_{1} \mathrm{~s}+\alpha_{2} \mathrm{t}+\alpha_{3} \mathrm{M} \\
& +\alpha_{4} \mathrm{I}+\mathrm{u}_{\mathrm{MFR}, \mathrm{t}}
\end{aligned}
$$

where the exogenous variables are as described in Table 1. All variables, except MFR and firm profits, are taken in natural logarithms, so the response effects may be inter-

TABLE 1

Data Description and Sources

\begin{tabular}{llcr}
\hline Variable & Type & Description & Source \\
\hline MFR & Endogenous & Matched firm return. Computed as described in text. & COMPUSTAT \\
MBR & Endogenous & Market-to-book ratio & COMPUSTAT \\
$\mathrm{R}$ & Endogenous & Sales revenue in millions of dollars & COMPUSTAT \\
$\mathrm{P}$ & Endogenous & Firm pretax profits in millions of dollars & COMPUSTAT \\
$\mathrm{A}$ & Endogenous & Advertising expenditures in thousands of dollars & Purchased from TNS \\
& & & Media Intelligence \\
RD & Endogenous & Firm R\&D expenditures in thousands of dollars & COMPUSTAT \\
$\mathrm{S}$ & Exogenous & Seasonality & \\
$\mathrm{T}$ & Exogenous & Time trend & \\
$\mathrm{M}$ & Exogenous & Mergers and/or acquisitions. \\
$\mathrm{I}$ & Exogenous & New product announcements, & FACTIVA and LexisNexis \\
$\mathrm{SP}$ & Exogenous & as operationalized by Sood and Tellis (2009) & CRSP 500 Index \\
SMB & Exogenous & Small minus big; Fama-French factor & Kenneth French Data Library \\
$\mathrm{HML}$ & Exogenous & High minus low; Fama-French factor & Kenneth French Data Library \\
$\mathrm{RMF}$ & Exogenous & Excess return on market & Kenneth French Data Library \\
& & (market return minus risk-free return; Fama-French factor & \\
\hline
\end{tabular}


preted as elasticities. However, some firms incur losses (negative profits) and negative MFR in certain periods in the sample. Although logarithms could still be taken using an additive constant, this is an arbitrary data adjustment that biases the elasticity interpretation, and therefore these variables are measured in levels.

Our analysis comprises five parts. First, we test for evolution of all the variables in our study. A priori, we expect to find the performance variables to be evolving, following random-walk theory and extant marketing literature (Dekimpe and Hanssens 1995a). Second, if evolution is found, we test for the presence of cointegration, or longterm coevolution. For example, profits and advertising expenditures may both be evolving, but if advertising budgets are set in function of profits, we would expect a longterm relationship between the two variables. Third, depending on the outcome of these tests, we estimate suitable VAR models.

Fourth, we derive impulse response functions (IRFs) from the estimated models. The IRFs trace the over-time impact of a unit shock to any endogenous variable on the other endogenous variables. Following Dekimpe and Hanssens (1999), we use generalized IRFs (or simultaneous shocking) to ensure that the ordering of variables in the system does not affect the results and also to account for contemporaneous or same-period effects. Given a VAR model in differences, the total shock effect at lag $\mathrm{k}$ is obtained by accumulating the lower-order IRFs. Following Dekimpe and Hanssens (1999) and Nijs and colleagues (2001), we determine the duration of the shock (maximum lag $\mathrm{k}$ ) as the last period in which the IRF value has a $|\mathrm{t}|$-statistic greater than 1 .

Fifth, we calculate the variance decomposition of the IRFs - that is, the percentage of the forecast error variance of firm value that is attributable to advertising shocks, separate from the contributions of $\mathrm{R} \& \mathrm{D}$, sales, and profit shocks (Nijs, Srinivasan, and Pauwels 2007). This analysis separates the direct impact of advertising on firm value from its indirect impact through sales and profits.

\section{Industry Setting and Data}

\section{Industry Setting}

We choose two industries, personal computers (PCs) and sporting goods, which were in different stages of the product life cycle, to help generalize our findings. The PC manufacturing industry experienced unprecedented growth in the 1990s (Figure 2) and was clearly in the growth phase of its life cycle. Dell, a relatively new participant, became the dominant PC manufacturer in the world, while more established competitors, such as HP and IBM, diversified their businesses (e.g., printers, services) to compensate for lost market share in the PC market. A survey of PC industry-related articles in the Wall Street Journal from 1991 to 2000 reveals that capturing market share with aggressive advertising and pricing was the focus of most PC manufacturers. Advertising messages "moved from emphasizing superior technology across offerings to highlighting perceived flaws in competitors" (Pope 1992, p. 1), while Dell highlighted its first place in the first J.D. Power customer satisfaction survey for the industry (Bartimo 1991, p. 6). Apple unveiled a \$100 million ad campaign in 1994 to launch its new iMac, partly with the intention of improving dealer morale (The Associated Press 1998). Overall, the major competitors in the industry were using advertising campaigns to establish positions of superiority in a growing market and, thus, to ensure long-term success.

In contrast, the sporting goods market was well established, with brands such as Nike and Reebok attempting to gain market share at the expense of smaller competitors, through aggressive advertising and celebrity endorsements. A survey of articles in the Wall Street Journal reveals the highly competitive nature of the market (Goldman 1993; Lipman 1991).

Thus, despite their different stages in the product life cycle, aggressive advertising was a key element in the strategies of firms in these two industries. For the PC industry, advertising aimed to establish the brand, while in the sporting goods industry, it aimed to gain market share over other established brands.

\section{Data}

We obtained 15 years (1991-2005) of monthly data on revenue, income, stock return, advertising, innovation announcements, and $\mathrm{R} \& \mathrm{D}$ expenditures for the leading competitors in the PC manufacturing industry (Apple, Compaq, Dell, HP, and IBM) and 10 years of data (1995-2004) for the sporting goods industry (Nike, Reebok, K-Swiss, and Skechers). We converted the stock return data to MFR data using the procedure outlined previously. (Table W1 in the Web Appendix provides descriptive statistics [see http://www.marketingpower.com/jmjan10].)

The five PC manufacturers accounted for $70 \%$ of the PC desktop market and almost $80 \%$ of the portable computer market at the end of 2005. Similarly, the leaders of the sporting goods market are represented in our sample, with the four firms accounting for $\$ 19$ billion in sales revenue for 2004, which is approximately $28 \%$ of the industry. While the PC manufacturing industry was in a growth phase in the 1990s (see Figure W1 in the Web Appendix at http://www.marketingpower.com/jmjan10), the sporting

\section{FIGURE 2}

Consumer and Investor Responses

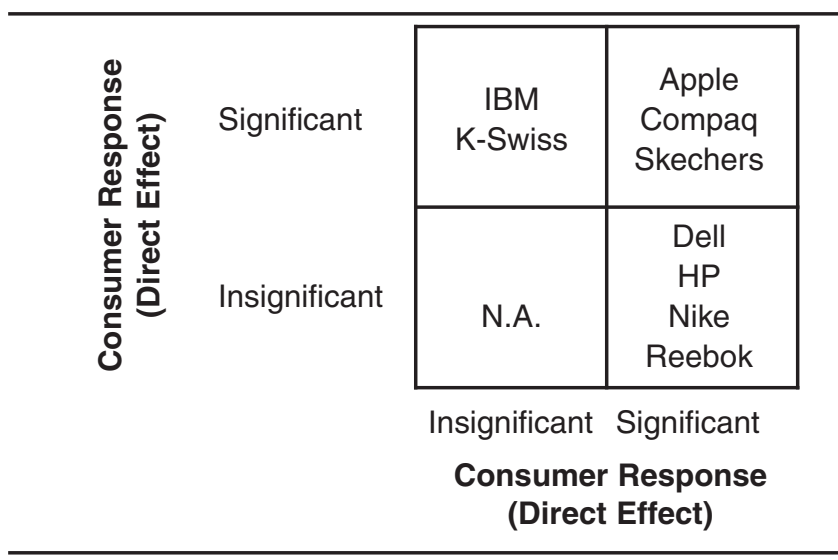

Notes: N.A. $=$ not applicable 
goods industry was in a mature phase (see Figure W2 in the Web Appendix). Dell emerged as the leading contender in the PC industry, while firms such as Apple struggled. In the sporting goods industry, however, Nike maintained its market leadership, despite the entrance of a new competitor (Skechers). This variability in performance and marketing efforts over time, both within each industry and across the two industries, provides a unique opportunity to study the long-term impact of advertising on stock return. Note also that though we do not explicitly control for differences in the firms' branding strategy, all the firms in our analysis employ corporate branding strategies, in which advertising has been shown to have a higher total impact on firm value (Rao, Agarwal, and Dahlhoff 2004).

We obtained data on income, stock return, sales, and R\&D expenditures from the CRSP and COMPUSTAT databases. We obtained firm-specific information and accounting data from the COMPUSTAT database. TNS Media Intelligence provided data on monthly advertising expenditures. We used the monthly Consumer Price Index to deflate all monetary variables. In addition, we collected innovation data on all the firms in our data set. Following Sood and Tellis (2009), we used Factiva and LexisNexis databases to find innovation-related announcements by these firms for the period of our data. The innovation variable is a count variable of the total number of announcements related to innovation for a firm/period. Announcements include those related to setup activities (e.g., grants, funded contracts), development activities (e.g., patents, preannouncements), and market activities (e.g., actual launches, initial shipment). Because, we are interested only in the total impact of innovation, we combine all these activities to form our innovation variable.

\section{Results}

We found that the results from using either stock return metric were comparable, so henceforth our discussion focuses on the findings we obtained from the MFR metric, the detailed results of which are available in the Web Appendix (http://www.marketingpower.com/jmjan10). We used augmented Dickey-Fuller tests to verify the presence of unit roots in the data. We found MFR to be stationary, as the finance literature predicts. Most sales revenues and advertising expenditures were evolving, in line with the empirical generalizations described by Dekimpe and Hanssens (1995b). ${ }^{4}$

The estimated VAR models, with the appropriate lags determined by the Schwarz BIC, showed a good fit, with Rsquare values ranging from .155 to .202 in changes (.936 to .990 in levels) for the PC industry and .183 to .310 in changes (.908 to .975 in levels) for the sporting goods industry (see Table 1). We verified model adequacy by performing two tests on the residuals. We test for the presence of serial correlation (Lagrange multiplier test) and heteroskedasticity (White's test). The results (see Table 2) indicate that the model residuals are white noise.

The accumulated advertising and R\&D elasticities (on sales) appear in Columns 2 and 3 of Table 3. The advertising elasticities have the expected magnitude for all firms under study and are statistically significant for three of the five firms in the PC industry and two firms in the sporting goods industry.

The positive sign and the small magnitude of R\&D elasticities are attributable to the uncertainty and the long gestation period typically associated with R\&D. Furthermore, the R\&D elasticities are persistent for Compaq, Dell, and IBM. Thus, a shock to R\&D expenditure has a long-term impact on firm sales revenue. We find that the R\&D elasticities for all sporting goods firms are insignificant, which may reflect the relatively low importance and variability of R\&D spending in this industry (approximately 2\%-3\% of sales). These results replicate previously established findings in the field and thus confirm their importance as covariates in our model.

Next, we examine the total effect of advertising on stock return. The last column in Table 3 shows the accumulated advertising elasticities on MFR. Note that these values combine the direct and indirect advertising effects on firm value over time. The effect of an advertising shock accumulates over 8, 6, 7, and 7 periods for Apple, Compaq, Dell, and $\mathrm{HP}$, respectively (the IRFs for these four firms are significant for 8, 6, 7, and 7 periods, respectively). Similarly, for Nike, Reebok, and Skechers, the advertising shock accumu-

${ }^{4}$ Detailed results are available on request.

TABLE 2

Model Fit and Residual Analysis

\begin{tabular}{|c|c|c|c|c|}
\hline & \multicolumn{2}{|c|}{ Fit Statistics } & \multicolumn{2}{|c|}{ Residual Test Statistics } \\
\hline & $\begin{array}{c}\mathrm{R}^{2} \\
\text { (in Changes) }\end{array}$ & $\begin{array}{c}\mathrm{R}^{2} \\
\text { (in Levels) }\end{array}$ & $\begin{array}{c}\text { Lagrange Multiplier } \\
p \text {-Values }\end{array}$ & $\begin{array}{c}\text { White } \\
p \text {-Values }\end{array}$ \\
\hline Apple & .156 & .941 & .989 & .965 \\
\hline Compaq & .193 & .937 & .913 & .994 \\
\hline Dell & .202 & .936 & .895 & .928 \\
\hline $\mathrm{HP}$ & .181 & .979 & .926 & .973 \\
\hline IBM & .155 & .990 & .871 & .905 \\
\hline Nike & .310 & .975 & .985 & .966 \\
\hline Reebok & .271 & .950 & .963 & .891 \\
\hline K-Swiss & .279 & .954 & .904 & .952 \\
\hline Skechers & .183 & .908 & .933 & .911 \\
\hline
\end{tabular}

Notes: The large $p$-values for residual statistics support the conclusion that there is no significant serial correlation and heteroskedasticity among residuals. 
TABLE 3

Customer and Investor Response Effects

\begin{tabular}{llll}
\hline & $\begin{array}{c}\text { Advertising } \\
\text { Elasticity }\end{array}$ & $\begin{array}{c}\text { R\&D } \\
\text { Elasticity }\end{array}$ & $\begin{array}{c}\text { Investor } \\
\text { Effects }\end{array}$ \\
\hline Apple & $.245^{\star \star *}$ & -.005 & $.010^{\star \star *}$ \\
Compaq & $.108^{\star \star *}$ & $.313^{\star *}$ & $.006^{\star \star \star}$ \\
Dell & .015 & $.122^{\star *}$ & $.007^{\star *}$ \\
HP & .013 & .008 & $.008^{\star *}$ \\
IBM & $.152^{\star *}$ & $.080^{\star}$ & .009 \\
Nike & .085 & .386 & $.005^{\star \star}$ \\
Reebok & .110 & .117 & $.007^{\star *}$ \\
K-Swiss & $.096^{\star *}$ & -.028 & .002 \\
Skechers & $.107^{\star}$ & -.076 & $.009^{\star}$ \\
\hline
\end{tabular}

${ }^{*} p<.10$ (one-tailed test).

${ }^{* *} p<.05$ (one-tailed test).

${ }^{* \star *} p<.01$ (one-tailed test).

Notes: After we adjust for the outliers by using dummy variables, the R\&D elasticity for Compaq falls to .131 , which is comparable to that of other firms. Advertising and R\&D elasticities are sales elasticities. Investor response effect is the elasticity of advertising on stock return.

lates over 6,6 , and 8 periods, respectively. Because changes in advertising spending are typically not reported to investors, the investors are informed only through actual exposure. This explains why the effect of a change in advertising is not absorbed in stock price instantly. Instead, there is a long-term effect beyond the first period, consistent with our expectation, and thus we find partial support for our hypothesis.

Apple, Compaq, Dell, and HP have positive and significant investor response elasticities, ranging from .007 to .01 . The elasticity for IBM is positive but not significantly different from zero, which may be explained by the large size and scope of this company's operations. Indeed, the PC division of IBM accounted for only $11 \%$ of its revenue, in contrast to $78 \%$ for Apple and $63 \%$ for Compaq.

In the sporting goods industry, three of the firms under study show positive and significant investor response elasticities, ranging from .005 to .009 . We find the highest elasticity for Skechers, which is also the youngest firm in this industry in our data. ${ }^{5}$

A noteworthy finding is that there are several cases of significant investor response even when there is no consumer response (Figure 2). ${ }^{6}$ Dell, HP, Nike, and Reebok show an increase in firm value even in the absence of any impact on sales. Thus, advertising may have a positive impact even if it has no measurable effect on sales. In contrast, IBM and K-Swiss have a consumer effect but no investor effect. This finding highlights the importance of focusing on a comprehensive long-term metric (e.g., firm value) when calculating the return on investment marketing instruments such as advertising.

5The elasticities we obtained are aggregate elasticities across all products of the firms. Although advertising expenditures and elasticities can vary across products, there is only one company stock price, which reflects overall performance, thus the need for aggregation.

${ }^{6}$ We thank an anonymous reviewer for this suggestion.
Overall, the investor response elasticities are of an order of magnitude that is lower than the typical sales response elasticities. This is to be expected because the dependent variable is excess return, which is the (scaled) residual of the random-walk process that is known to underlie the behavior of stock prices. Even so, these low elasticities can generate a sizable economic impact, as we explore subsequently. ${ }^{7}$

\section{Variance Decomposition}

To measure the direct impact of advertising on stock return relative to other factors, we examine the forecast error variance decomposition of firm value. The forecast error variance decomposition calculates the contribution of the various covariates to the forecast variance of MFR. The results are in Table 4, Panels A and B. This analysis is meaningful only for firms with significant investor response elasticities from the IRF analysis.

Table 4, Panels A and B, shows that advertising expenditures initially have a small impact on MFR. In the first few periods after the impulse, firm value is largely determined by past value, as predicted by the random-walk model. However, the impact of advertising increases over time (see, e.g., Figure W3 in the Web Appendix at http:// www.marketingpower.com/jmjan10). Thus, for Apple, advertising explains only $.569 \%$ of the forecast error variance in Period 1 but $4.68 \%$ of the variance in Period 8 . Unlike the IRFs, the variance decomposition does not involve simultaneous shocking, and thus the percentages represented here indicate the impact of advertising on firm value beyond its effect on sales and profits. ${ }^{8}$ In conclusion, we find that advertising shocks often increase firm value in the long run and beyond the impact that might be expected from their effect on revenues and profits.

\section{Impact of Competitive Advertising}

We verify how robust our results are to the inclusion of competitive advertising by reestimating our model (1) for each firm after including a competition variable $\left(\Delta \mathrm{C}_{\mathrm{t}}\right)$. Because we lack sufficient degrees of freedom to simultaneously include advertising expenditures from all competing firms in one model, we estimate competition in pairs of firms. ${ }^{9}$ Thus, for the PC industry, for which we have five firms in our data set, we estimate 20 separate models. The analysis reveals cointegration between the advertising expenditures of competing firms, prompting the use of vector error correction models (Dekimpe and Hanssens 1999). After including the competitor advertising variable $\left(\Delta \mathrm{C}_{\mathrm{t}}\right)$, we estimate a system of the following form:

${ }^{7}$ The investor response elasticities for innovation and promotion in the automobile industry are even lower but still statistically significant (see Pauwels et al. 2004).

${ }^{8}$ We used Cholesky decomposition to estimate the forecast error variance decomposition. The results are not sensitive to the ordering of the variables.

9This may bias our coefficients if the advertising expenditures are correlated. However, we find that all correlations among advertising variables are less than .04 in magnitude, which virtually eliminates the risk of bias. 
TABLE 4

Forecast Error Variance Decompositions

\begin{tabular}{|c|c|c|c|c|c|c|c|c|}
\hline \multicolumn{9}{|c|}{ A: PC Industry } \\
\hline \multirow[b]{2}{*}{ Period } & \multicolumn{2}{|c|}{ Apple } & \multicolumn{2}{|c|}{ Compaq } & \multicolumn{2}{|c|}{ Dell } & \multicolumn{2}{|c|}{ HP } \\
\hline & MFR & Adv & MFR & Adv & MFR & Adv & MFR & Adv \\
\hline 1 & 87.481 & $.596^{\mathrm{a}}$ & 92.971 & $1.435^{a}$ & 94.183 & $.943^{a}$ & 97.772 & $.953^{2}$ \\
\hline 2 & 83.571 & $2.038^{a}$ & 90.315 & $2.856^{a}$ & 91.632 & $2.644^{a}$ & 84.369 & $2.010^{2}$ \\
\hline 3 & 80.287 & 3.670 & 84.583 & 3.241 & 88.742 & 2.997 & 81.189 & 3.134 \\
\hline 4 & 78.733 & 4.587 & 83.875 & 4.542 & 84.950 & 4.201 & 80.905 & 3.124 \\
\hline 5 & 78.488 & 4.651 & 83.489 & 5.338 & 84.112 & 5.184 & 80.849 & 3.248 \\
\hline 6 & 78.442 & 4.679 & 83.433 & 5.452 & 82.895 & 5.523 & 80.840 & 3.266 \\
\hline 7 & 78.440 & 4.679 & 83.330 & 5.676 & 80.799 & 5.715 & 80.831 & 3.285 \\
\hline 8 & 78.438 & 4.681 & 83.327 & 5.677 & 79.854 & 5.692 & 80.828 & 3.288 \\
\hline 9 & 78.438 & 4.681 & 83.308 & 5.716 & 79.850 & 5.726 & 80.828 & 3.289 \\
\hline 10 & 78.438 & 4.681 & 83.307 & 5.717 & 79.849 & 5.727 & 80.827 & 3.290 \\
\hline \multicolumn{9}{|c|}{ B: Sporting Goods Industry } \\
\hline & \multicolumn{3}{|c|}{ Nike } & \multicolumn{2}{|c|}{ Reebok } & \multicolumn{3}{|c|}{ Skechers } \\
\hline Period & MFR & & & MFR & Adv & & & Adv \\
\hline 1 & 98.268 & & & 99.116 & $.183^{a}$ & & & $.095^{a}$ \\
\hline 2 & 96.580 & & & 96.734 & $.639^{a}$ & & & $1.452^{\mathrm{a}}$ \\
\hline 3 & 91.414 & & & 91.092 & $.822^{a}$ & & & $1.954^{a}$ \\
\hline 4 & 89.126 & & & 90.313 & $1.464^{a}$ & & & 2.822 \\
\hline 5 & 88.960 & & & 89.881 & $1.894^{a}$ & & & 3.223 \\
\hline 6 & 88.696 & & & 83.433 & $1.951^{\mathrm{a}}$ & & & 3.523 \\
\hline 7 & 88.600 & & & 89.710 & 2.065 & & & 3.528 \\
\hline 8 & 88.588 & & & 89.707 & 2.065 & & & 3.529 \\
\hline 9 & 88.574 & & & 89.687 & 2.085 & & & 3.529 \\
\hline 10 & 88.564 & & & 89.685 & 2.086 & & & 3.529 \\
\hline
\end{tabular}

aNot significant. All other figures are significant at $p<.05$.

Notes: Read: If MFR for Apple is projected $1-10$ periods into the future, only $.596 \%$ of the forecast error variance in Period 1 is explained by shocks to advertising expenditures (Adv). This percentage grows to $4.681 \%$ of the variance by Period 10 . In contrast, $87.481 \%$ of the forecast error variance in Period 1 is explained by momentum (variance in past values of MFR). This percentage declines to $78.438 \%$ of the variance by Period 10.

(3)

$$
\begin{aligned}
& {\left[\begin{array}{l}
\Delta \mathrm{MFR}_{\mathrm{t}} \\
\Delta \mathrm{R}_{\mathrm{t}} \\
\Delta \mathrm{P}_{\mathrm{t}} \\
\Delta \mathrm{A}_{\mathrm{t}} \\
\Delta \mathrm{RD}_{\mathrm{t}} \\
\Delta \mathrm{C}_{\mathrm{t}}
\end{array}\right]=\left(\begin{array}{cccccc}
\alpha_{\mathrm{MFR}} & 0 & 0 & 0 & 0 & 0 \\
0 & \alpha_{\mathrm{R}} & 0 & 0 & 0 & 0 \\
0 & 0 & \alpha_{\mathrm{P}} & 0 & 0 & 0 \\
0 & 0 & 0 & \alpha_{\mathrm{A}} & 0 & 0 \\
0 & 0 & 0 & 0 & \alpha_{\mathrm{RD}} & 0 \\
0 & 0 & 0 & 0 & 0 & \alpha_{\mathrm{C}}
\end{array}\right)\left[\begin{array}{l}
\mathrm{e}_{\mathrm{MFR}, \mathrm{t}-1} \\
\mathrm{e}_{\mathrm{R}, \mathrm{t}-1} \\
\mathrm{e}_{\mathrm{P}, \mathrm{t}-1} \\
\mathrm{e}_{\mathrm{A}, \mathrm{t}-1} \\
\mathrm{e}_{\mathrm{RD}, \mathrm{t}-1} \\
\mathrm{e}_{\mathrm{C}, \mathrm{t}-1}
\end{array}\right]} \\
& +\sum_{\mathrm{j}=1}^{\mathrm{J}}\left(\begin{array}{l}
\pi_{11}^{\mathrm{j}} \pi_{12}^{\mathrm{j}} \pi_{13}^{\mathrm{j}} \pi_{14}^{\mathrm{j}} \pi_{15}^{\mathrm{j}} \pi_{16}^{\mathrm{j}} \pi_{22}^{\mathrm{j}} \pi_{23}^{\mathrm{j}} \pi_{24}^{\mathrm{j}} \pi_{25}^{\mathrm{j}} \pi_{26}^{\mathrm{j}} \pi_{32}^{\mathrm{j}} \pi_{33}^{\mathrm{j}} \pi_{34}^{\mathrm{j}} \pi_{35}^{\mathrm{j}} \pi_{36}^{\mathrm{j}} \\
\pi_{41}^{\mathrm{j}} \pi_{42}^{\mathrm{j}} \pi_{43}^{\mathrm{j}} \pi_{44}^{\mathrm{j}} \pi_{45}^{\mathrm{j}} \pi_{46}^{\mathrm{j}} \\
\pi_{51}^{\mathrm{j}} \pi_{52}^{\mathrm{j}} \pi_{53}^{\mathrm{j}} \pi_{54}^{\mathrm{j}} \pi_{55}^{\mathrm{j}} \pi_{56}^{\mathrm{j}} \\
\pi_{61}^{\mathrm{j}} \pi_{62}^{\mathrm{j}} \pi_{63}^{\mathrm{j}} \pi_{64}^{\mathrm{j}} \pi_{65}^{\mathrm{j}} \pi_{66}^{\mathrm{j}}
\end{array}\right)\left[\begin{array}{l}
\Delta \mathrm{MFR}_{\mathrm{t}-\mathrm{j}} \\
\Delta \mathrm{R}_{\mathrm{t}-\mathrm{j}} \\
\Delta \mathrm{P}_{\mathrm{t}-\mathrm{j}} \\
\Delta \mathrm{A}_{\mathrm{t}-\mathrm{j}} \\
\Delta \mathrm{RD} \\
\mathrm{t}-\mathrm{j} \\
\Delta \mathrm{C}_{\mathrm{t}-\mathrm{j}}
\end{array}\right]+\left[\begin{array}{l}
\mathrm{u}_{\mathrm{MFR}, \mathrm{t}} \\
\mathrm{u}_{\mathrm{R}, \mathrm{t}} \\
\mathrm{u}_{\mathrm{P}, \mathrm{t}} \\
\mathrm{u}_{\mathrm{A}, \mathrm{t}} \\
\mathrm{u}_{\mathrm{RD}, \mathrm{t}} \\
\mathrm{u}_{\mathrm{C}, \mathrm{t}}
\end{array}\right] .
\end{aligned}
$$

The addition of the extra vector of the error correction variables $\left(e_{\bullet}, t-1\right)$ in this system of equations results in additional coefficients to be estimated. To avoid overparameter- ization, we restrict insignificant coefficients from Model 1 to be zero when estimating Model 3. We difference the variables if we find them to be nonstationary. The investor response elasticities obtained from this model appear in Table 5.

The competitive elasticities are predominantly negative for Apple, Compaq, and Dell and are insignificant for HP and IBM. The own investor response elasticities (which are the average elasticities for the four paired models estimated for each firm), after accounting for competition, appear as the diagonal values in Table 5. A comparison with the values in Table 3 reveals that the own elasticities retain their sign and significance, while their magnitudes are marginally different. Overall, the inclusion of competition does not alter the support for $\mathrm{H}_{1}$.

The competitive elasticities can be better understood in the context of the relative market valuations of these firms (see Figure W4 in the Web Appendix at http://www.marketing power.com/jmjan10). Competitive elasticities of small market valuation share firms are negative (and generally significant), while those of large market valuation share firms are 
not significant. A firm's advertising expenditure has a negative impact on the market valuation of competing firms if they are of a comparable size and no impact on firms that are much larger (in market valuation) than itself. This result can be explained by the finding that the cross-sales elasticities of the marketing expenditures are not significant. ${ }^{10}$ Thus, the inclusion of competition provides the insight that advertising not only affects own firm valuation positively but also can have a negative effect on competitors.

\section{Empirical Validation}

To check the validity of our model, we conducted three tests. First, we check for the presence of structural breaks in the data. Because these data span a period of 15 years for the PC industry and 10 years for the sporting goods industry, structural breaks in one or more of the series could occur. If a series in our sample were comprised of two stationary regimes separated by a structural break, it could appear to be evolving (Perron 1990). To guard against this, we carried out rolling-window unit root tests (Pauwels and Hanssens 2007): We select a suitably long window of observations (40 in this case), and the window is moved along the length of the series (180 observations for PCs and 120 for sporting goods). We then compare all the Dickey-Fuller statistics with their unit root critical values. These rollingwindow unit root tests indicated no evidence of structural breaks in the data.

Second, we test for the stability of the parameters obtained in our model. We obtain recursive estimates for the parameters in the stock return equation from the VAR, using a rolling-window data sample. The results indicate that parameters are stable.

Third, we test for the possible effect of temporal aggregation in our series. Although the MFR and advertising series were available at the monthly level, sales, R\&D, and profit series were only available quarterly. Using all series at the quarterly level causes a degrees-of-freedom problem, unless the data can be pooled across firms (Bass and Wittink 1975). Thus, we reestimated our VAR model in quarterly panel form for each industry. We tested the poolability

\section{${ }^{10}$ Detailed results are available on request. \\ TABLE 5 \\ Investor Response Effects with Competitive Advertising}

\begin{tabular}{lccccc}
\hline & \multicolumn{5}{c}{ Impact on } \\
\cline { 2 - 6 } Impact of & Apple & Compaq & Dell & HP & IBM \\
\hline Apple & $.0082^{* *}$ & $-.0019^{*}$ & .0000 & .0000 & .0000 \\
Compaq & $-.0010^{\star}$ & $.0076^{\star *}$ & -.0010 & .0000 & .0000 \\
Dell & $-.0022^{*}$ & -.0016 & $.0072^{*}$ & -.0010 & -.0014 \\
HP & .0000 & -.0021 & .0019 & .0069 & .0011 \\
IBM & .0000 & .0000 & .0016 & .0018 & .0053 \\
\hline
\end{tabular}

${ }^{*} p<.10$ (two-tailed test).

${ }^{* *} p<.05$ (two-tailed test)

Notes: Coefficients smaller than $10^{-4}$ are displayed as .0000 . The impact of Dell advertising on Apple can be read as follows: A $1 \%$ increase in Dell advertising results in a .0022 unit reduction in the stock return of Apple. of the model using the Chow F-test, extended to a system of equations (Chow 1960):

$$
\mathrm{F}=\frac{(\mathrm{RRSS}-\mathrm{URSS}) / \mathrm{r}}{\mathrm{URSS} / \mathrm{d}},
$$

where RRSS is the restricted (pooled model) sum of squared residuals, URSS is the sum of squared residuals in the unrestricted model (trace of the variance-covariance matrix), $r$ is the number of linearly independent restrictions, and $\mathrm{d}$ is the number of degrees of freedom for the unrestricted model. For a model with firm-specific intercepts and fixed response effects, this test yields F-values of 2.27 (PC) and 2.13 (sporting goods), which are below the critical value of 2.4 at the $95 \%$ confidence level. Thus, we conclude that the data are partially poolable, with firm-varying intercepts and common slopes:

(4)

$$
\begin{aligned}
& {\left[\begin{array}{l}
\Delta \mathrm{MFR}_{\mathrm{i}, \mathrm{t}} \\
\Delta \mathrm{R}_{\mathrm{i}, \mathrm{t}} \\
\Delta \mathrm{A}_{\mathrm{i}, \mathrm{t}} \\
\Delta \mathrm{P}_{\mathrm{i}, \mathrm{t}} \\
\Delta \mathrm{RD}_{\mathrm{i}, \mathrm{t}}
\end{array}\right]=\left[\tilde{\gamma}+\tilde{\beta}_{\text {Compaq }}+\tilde{\beta}_{\text {Dell }}+\tilde{\beta}_{\mathrm{HP}}+\tilde{\beta}_{\mathrm{IBM}}\right]} \\
& +\sum_{j=1}^{\mathrm{J}}\left[\begin{array}{lllll}
\pi_{11}^{\mathrm{j}} & \pi_{12}^{\mathrm{j}} & \pi_{13}^{\mathrm{j}} & \pi_{14}^{\mathrm{j}} & \pi_{15}^{\mathrm{j}} \\
\pi_{21}^{\mathrm{j}} & \pi_{22}^{\mathrm{j}} & \pi_{23}^{\mathrm{j}} & \pi_{24}^{\mathrm{j}} & \pi_{25}^{\mathrm{j}} \\
\pi_{31}^{\mathrm{j}} & \pi_{32}^{\mathrm{j}} & \pi_{33}^{\mathrm{j}} & \pi_{34}^{\mathrm{j}} & \pi_{35}^{\mathrm{j}} \\
\pi_{41}^{\mathrm{j}} & \pi_{42}^{\mathrm{j}} & \pi_{43}^{\mathrm{j}} & \pi_{44}^{\mathrm{j}} & \pi_{45}^{\mathrm{j}} \\
\pi_{51}^{\mathrm{j}} & \pi_{52}^{\mathrm{j}} & \pi_{53}^{\mathrm{j}} & \pi_{54}^{\mathrm{j}} & \pi_{55}^{\mathrm{j}}
\end{array}\right]\left[\begin{array}{l}
\Delta \mathrm{MFR}_{\mathrm{i}, \mathrm{t}-\mathrm{j}} \\
\Delta \mathrm{R}_{\mathrm{i}, \mathrm{t}-\mathrm{j}} \\
\Delta \mathrm{A}_{\mathrm{i}, \mathrm{t}-\mathrm{j}} \\
\Delta \mathrm{P}_{\mathrm{i}, \mathrm{t}-\mathrm{j}} \\
\Delta \mathrm{RD}_{\mathrm{i}, \mathrm{t}-\mathrm{j}}
\end{array}\right]+\left[\begin{array}{l}
\mathrm{u}_{\mathrm{MFR}, \mathrm{i}, \mathrm{t}} \\
\mathrm{u}_{\mathrm{R}, \mathrm{i}, \mathrm{t}} \\
\mathrm{u}_{\mathrm{A}, \mathrm{i}, \mathrm{t}} \\
\mathrm{u}_{\mathrm{P}, \mathrm{i}, \mathrm{t}} \\
\mathrm{u}_{\mathrm{RD}, \mathrm{i}, \mathrm{t}}
\end{array}\right] .
\end{aligned}
$$

In Equation 3, $\tilde{\gamma}$ is the common vector of intercepts, and $\tilde{\beta}_{\mathrm{i}}$ is a $(5 \times 1)$ vector of company specific dummy variables. Thus, $\tilde{\beta}_{\text {Compaq }}$ is 1 when variables correspond to Compaq and 0 otherwise.

The R-square in changes for the panel VAR model is .237 (.939 in levels) for the PC industry and .269 (.966 in levels) for the sporting goods industry. The optimal number of lags, determined by the Schwarz BIC, is 2, and the residual portmanteau test indicates that residuals are white noise. The most important confirmatory result is that the advertising elasticity of MFR is significant and positive for both industries (PC: .007, t-statistic $=1.98$; sporting goods: .006, t-statistic $=1.90)$. Thus, our generalized estimate of the long-term advertising effect on firm valuation is between .006 and .007 , and both the structural-break test and the temporal-aggregation test validate the results of our model.

\section{Market Capitalization Projections of Increased Advertising Spending}

The estimated investor response elasticities can be used to project the impact on market capitalization of various changes in the advertising level of firms with significant response effects. These forecasts quantify the economic impact of advertising spending on firm value. Indeed, although the elasticities are small in magnitude, they can translate into a substantial impact on market capitalization. 
Table 6, Panel A, shows the change in market valuation for a $10 \%$ increase in advertising spending for the PC brands with significant customer and investor response to advertising (i.e., Apple and Compaq). No competitive reaction takes place in these scenarios. In projecting the market valuation figures, we adjusted for the increased advertising spending and the effects of a reduction in firm profits (and thus stock returns). Compaq achieves gains in total market value that exceed the loss from the implied profit reduction in all four years of the simulation, while Apple gains in only one of the four years. These results derive from the opposing forces of cost increases (profit reduction), revenue and profit enhancement, and brand equity gains.

In contrast to the no-reaction scenario in Table 6, Panel A, the scenario in Table 6, Panel B, shows the change assuming that competitors respond by increasing their advertising expenditures as well. We consider the competitor with the highest cross-elasticity from Table 5 the responder. In all cases, the direct effect of advertising on valuation is insufficient to justify a sizable increase in spending (i.e., a consumer response [indirect] effect is required as well). Therefore, we examine more closely the profit-maximizing advertising spending level as well.

\section{Profit-Maximizing Spending}

Using the well-known Dorfman-Steiner conditions (see Dorfman and Steiner 1954), we write the optimal advertising for a profit-maximizing firm as follows:

$$
\operatorname{Adv}_{\mathrm{opt}, \mathrm{t}}=\left(\text { Sales }_{\mathrm{b}, \mathrm{t}} \times \mathrm{G}_{1} \times \varepsilon_{\mathrm{A}}\right)^{\frac{1}{1-\varepsilon_{\mathrm{A}}}}
$$

where $\mathrm{Adv}_{\text {opt,t }}$ is the optimal advertising spend, Sales $\mathrm{b}_{\mathrm{t}, \mathrm{t}}$ is baseline sales (sales due to factors other than advertising), $\mathrm{G}_{\mathrm{t}}$ is gross margin at time $\mathrm{t}$, and $\varepsilon_{\mathrm{A}}$ is the advertising elasticity. We obtain the baseline sales with the following:

$$
\operatorname{Sales}_{b, t}=\frac{\operatorname{Sales}_{t}}{\operatorname{Adv}_{t}^{\varepsilon_{\mathrm{A}}}} .
$$

We obtained gross margins from annual financial reports for the respective firms. Using these data, we can derive the annual Dorfman-Steiner optimal advertising budgets and compare them with the actual expenditures. Table 7 provides these comparisons for the 1997-2000 period.

We conclude that an increase in advertising spending results in a gain in market capitalization only when the initial advertising expenditure is between $94 \%$ and $117 \%$ of the Dorfman-Steiner optimal level. Overall, our conclusion

TABLE 6

\begin{tabular}{|c|c|c|c|c|c|c|c|c|}
\hline \multicolumn{9}{|c|}{ A: $10 \%$ Advertising Increase } \\
\hline Year & Current MV & $\begin{array}{c}\text { Increase Due } \\
\text { to Revenue }\end{array}$ & \multicolumn{2}{|c|}{$\begin{array}{l}\text { Increase Due } \\
\text { to Direct Effect }\end{array}$} & \multicolumn{2}{|c|}{$\begin{array}{l}\text { Reduction Due } \\
\text { to Cost }\end{array}$} & New MV & Net Gain \\
\hline \multicolumn{9}{|l|}{ Apple } \\
\hline 1997 & $\$ 1,500$ & $\$ 1.42$ & \multicolumn{2}{|c|}{$\$ .08$} & \multicolumn{2}{|r|}{$\$ 2.72$} & $\$ 1,499$ & No \\
\hline 1998 & $\$ 3,700$ & $\$ 3.51$ & \multicolumn{2}{|c|}{$\$ .19$} & \multicolumn{2}{|r|}{$\$ 4.53$} & $\$ 3,699$ & No \\
\hline 1999 & $\$ 12,700$ & $\$ 12.06$ & \multicolumn{2}{|c|}{$\$ .64$} & \multicolumn{2}{|r|}{$\$ 5.36$} & $\$ 12,707$ & Yes \\
\hline 2000 & $\$ 3,700$ & $\$ 3.51$ & \multicolumn{2}{|c|}{$\$ .19$} & \multicolumn{2}{|r|}{$\$ 8.06$} & $\$ 3,696$ & No \\
\hline \multicolumn{9}{|c|}{ Compaq } \\
\hline 1997 & $\$ 35,600$ & $\$ 23.52$ & \multicolumn{2}{|c|}{$\$ 1.40$} & \multicolumn{2}{|r|}{$\$ 4.15$} & $\$ 35,621$ & Yes \\
\hline 1998 & $\$ 57,800$ & $\$ 38.18$ & \multicolumn{2}{|c|}{$\$ 2.28$} & \multicolumn{2}{|r|}{$\$ 5.42$} & $\$ 57,835$ & Yes \\
\hline 1999 & $\$ 36,600$ & $\$ 24.18$ & \multicolumn{2}{|c|}{$\$ 1.44$} & \multicolumn{2}{|r|}{$\$ 6.04$} & $\$ 36,620$ & Yes \\
\hline 2000 & $\$ 19,800$ & $\$ 13.08$ & \multicolumn{2}{|c|}{$\$ .78$} & \multicolumn{2}{|r|}{$\$ 5.23$} & $\$ 19,809$ & Yes \\
\hline \multicolumn{9}{|c|}{ B: $10 \%$ Increase in Own and Competitive Advertising } \\
\hline Year & Current MV & $\begin{array}{l}\text { Increase } \\
\text { Due to } \\
\text { Revenue }\end{array}$ & $\begin{array}{l}\text { Increase } \\
\text { Due to } \\
\text { Direct Effect }\end{array}$ & $\begin{array}{c}\text { Redu } \\
\text { Due t }\end{array}$ & $\begin{array}{l}\text { ction } \\
\text { Cost }\end{array}$ & $\begin{array}{l}\text { Reduction } \\
\text { Due to } \\
\text { Competition }\end{array}$ & New MV & Net Gain \\
\hline \multicolumn{9}{|l|}{ Apple } \\
\hline 1997 & $\$ 1,500$ & $\$ 1.42$ & $\$ .08$ & & 72 & $\$ .42$ & $\$ 1,499$ & No \\
\hline 1998 & $\$ 3,700$ & $\$ 3.51$ & $\$ .19$ & & & $\$ 1.04$ & $\$ 3,699$ & No \\
\hline 1999 & $\$ 12,700$ & $\$ 12.06$ & $\$ .64$ & & & $\$ 3.56$ & $\$ 12,707$ & Yes \\
\hline 2000 & $\$ 3,700$ & $\$ 3.51$ & $\$ .19$ & & 06 & $\$ 1.04$ & $\$ 3,696$ & No \\
\hline \multicolumn{9}{|c|}{ Compaq } \\
\hline 1997 & $\$ 35,600$ & $\$ 23.52$ & $\$ 1.40$ & & .15 & $\$ 6.41$ & $\$ 35,621$ & Yes \\
\hline 1998 & $\$ 57,800$ & $\$ 38.18$ & $\$ 2.28$ & & .42 & $\$ 10.40$ & $\$ 57,835$ & Yes \\
\hline 1999 & $\$ 36,600$ & $\$ 24.18$ & $\$ 1.44$ & & .04 & $\$ 6.59$ & $\$ 36,620$ & Yes \\
\hline 2000 & $\$ 19,800$ & $\$ 13.08$ & $\$ .78$ & & .23 & $\$ 3.56$ & $\$ 19,809$ & Yes \\
\hline
\end{tabular}

Market Valuation Impact

Notes: All figures are in millions of dollars. MV = market valuation. 
TABLE 7

Comparison of Actual Advertising Expenditures with Optimal

\begin{tabular}{ccrc}
\hline & $\begin{array}{c}\text { Dorfman- } \\
\text { Steiner Optimal } \\
\text { Advertising } \\
\text { Expenditure }\end{array}$ & $\begin{array}{c}\text { Actual } \\
\text { Expenditure }\end{array}$ & $\begin{array}{c}\text { Deviation from } \\
\text { Optimal }\end{array}$ \\
\hline Apple & & & \\
1997 & $\$ 319,134$ & $\$ 406,760$ & $27 \%$ \\
1998 & $\$ 299,814$ & $\$ 676,570$ & $126 \%$ \\
1999 & $\$ 426,437$ & $\$ 400,530$ & $-6 \%$ \\
2000 & $\$ 411,020$ & $\$ 1,203,630$ & $193 \%$ \\
Compaq & & & \\
1997 & $\$ 797,084$ & $\$ 923,330$ & $16 \%$ \\
1998 & $\$ 885,658$ & $\$ 720,582$ & $-19 \%$ \\
1999 & $\$ 1,029,938$ & $\$ 1,204,020$ & $17 \%$ \\
2000 & $\$ 1,199,531$ & $\$ 1,163,920$ & $-3 \%$ \\
\hline
\end{tabular}

Notes: All figures are in hundreds of dollars.

is that the market capitalization effect of increased advertising spending can be sizable, but it is still subject to economic reasonableness: There must be a consumer response impact to supplement the direct effect, and the spending must be in the vicinity of the profit-maximizing level.

\section{Conclusions and Further Research}

This study provides conceptual and empirical evidence of a positive relationship between advertising expenditures and the market value of firms. The results show that there is an investor response effect of advertising beyond its expected effects through revenue and profit sales increases. The pooled estimate of the investor response elasticity in two industries is between .006 and .007 .

The findings have several important implications for managers. First, we show that advertising has a double impact on firm value - through direct and indirect routeswhich provides a strong justification for investments in advertising. Second, we demonstrate that advertising may have an investor impact even if there is no tangible consumer impact. This implies that managers should be cognizant of the total impact of advertising spending, not only the near-term sales or profit impact. Third, we highlight the impact of competitive advertising on own firm valuation. Managers should be especially cognizant of aggressive advertising campaigns by firms of similar size because they have the potential to negatively affect own firm stock price. Finally, we show the importance of keeping advertising expenditures reasonably close to the optimum. In the industries we study, the market penalizes firms for significant deviations from optimal spending in both directions.

Several limitations help set an agenda for further research. First, we studied only two industries-PC manu- facturers and sporting goods. A replication of the model in other industries and periods would provide further crossvalidation of the results. Second, this work could be extended to the differential impact of advertising media on market valuation. Third, it would be worthwhile examining the hypothesis for firms that use either a house-of-brands or a mixed-branding strategy. Finally, our model could be extended to separate the volume effect of branding from the price premium effect (Ailawadi, Lehmann, and Neslin 2003).

There are some limitations in our data set as well. As in most valuation studies, revenue and profit data are aggregated to the firm level (i.e., they are not broken down by division). When applied to tracking stocks for which there is a closer match between the product category and the corporate identity, our approach may reveal higher advertisingto-market value elasticities. Similarly, our advertising data did not include a breakdown of spending on product advertising versus brand image advertising. Partially as a result of this, some of our elasticities have relatively modest t-statistics.

Nevertheless, the results succeed in linking advertising directly to firm value and thus underscore the importance of building intangible assets. The direct relationship between advertising and firm value provides managers with a new, more comprehensive metric of advertising effectiveness (i.e., firm value). Although the investor response elasticity is small in magnitude, advertising can induce substantial changes to firm valuations.

Our findings open up several areas for further research. Among these, the presence of a long-term effect of advertising on the market value of a firm, possibly through the creation of brand equity, suggests that any action that grows brand equity could affect firm value. Thus, order of entry, distribution intensity, or even choice of media may be hypothesized to affect the brand equity of a firm and, thus, its market value. Another area of interest is the potential relationship between the quality of advertising execution and its impact on firm value. Anecdotally, Apple is highly regarded for its advertising campaigns. Its "1984" advertisement was rated the "Best Ever Super Bowl Ad" by ESPN and won a CLIO award (the world's largest advertising competition). Between 1990 and 1998, various Apple Computers advertisements won 23 CLIO awards in different categories, compared with 1, 0, 7, and 11 awards for Compaq, Dell, HP, and IBM, respectively. Further research should examine the extent to which such differences in perceived advertising quality have an influence on the investor community. Finally, because market value is affected by both the level and the volatility of sales revenue, further research should examine the effect of marketing variables on volatility. 


\section{REFERENCES}

Aaker, David A. (1991), Managing Brand Equity. New York: The Free Press.

_ and Robert Jacobson (1994), "The Financial Information Content of Perceived Quality," Journal of Marketing Research, 31 (May), 191-201.

- and (2001), "The Value Relevance of Brand Attitude in High-Technology Markets," Journal of Marketing Research, 38 (November), 485-93.

Ailawadi, Kusum, Donald Lehmann, and Scott Neslin (2003), "Revenue Premium as an Outcome Measure of Brand Equity," Journal of Marketing, 67 (October), 1-17.

The Associated Press (1998), "Apple Spending \$100 Million in Advertising for New iMac Computer," (August 13).

Barber, Brad M. and John D. Lyon (1997), "Detecting Long-Run Abnormal Stock Returns: The Empirical Power and Specification of Test Statistics," Journal of Financial Economics, 43 (3), 341-72.

Bartimo, Jim (1991), "Marketing and Media," The Wall Street Journal, (May 14), 6.

Bass, Frank M. and Dick R. Wittink (1975), "Pooling Issues and Methods in Regression Analysis with Examples in Marketing Research," Journal of Marketing Research, 12 (November), 414-25.

Chan, Louis K.C., Josef Lakonishok, and Theodore Sougiannis (2001), "The Stock Market Valuation of Research and Development Expenditure," Journal of Finance, 56 (6), 2431-56.

Chaney, Paul K., Timothy M. Devinney, and Russell S. Winer (1991), "The Impact of New Product Introductions on the Market Value of Firms," Journal of Business, 64 (4), 573-610.

Chauvin, Keith W. and Mark Hirschey (1993), "Advertising, R\&D Expenditures and the Market Value of the Firm," Financial Management, 22 (4), 128-40.

Chhaochharia, Vidhi and Yaniv Grinstein (2007), "Corporate Governance and Firm Value: The Impact of the 2002 Governance Rules," Journal of Finance, 62 (4), 1789-1825.

Chow, G. (1960), "Tests of Equality Between Sets of Coefficients in Two Linear Regressions," Econometrica, 28 (3), 591-605.

Cockburn, Iain and Zvi Griliches (1988), "Industry Effects and Appropriability Measures in the Stock Market's Evaluation of R\&D and Patents," American Economic Review, 78 (2), 419-23.

Dekimpe, Marnik G. and Dominique M. Hanssens (1995a), "Empirical Generalizations About Market Evolution and Stationarity" Marketing Science, 14 (3), 1-21.

_ a - and (1995b), "The Persistence of Marketing Effects on Sales," Marketing Science, 14 (1), 1-21.

_ and (1999), "Sustained Spending and Persistent Response: A New Look at Long-Term Marketing Profitability," Journal of Marketing Research, 23 (November), 397-412.

—, , and Jorge Silva-Risso (1999), "Long-Run Effects of Price Promotions in Scanner Markets," Journal of Econometrics, 89 (1-2), 269-91.

Dorfman, R. and P.O. Steiner (1954), "Optimal Advertising and Optimal Quality," American Economic Review, 44 (5), 826-36.

Erickson, Gary and Robert Jacobson (1992), "Gaining Competitive Advantage Through Discretionary Expenditures: The Returns to R\&D and Advertising," Management Science, 38 (9), 1264-79.

Fama, Eugene F. (1970), "Efficient Capital Markets: A Review of Theory and Empirical Work," Journal of Finance, 25 (2), $383-417$.

_ _ and Kenneth French (1992), "The Cross-Section of Expected Stock Returns," Journal of Finance, 47 (2), 427-65.

Fornell, Claes, Sunil Mithas, Forrest V. Morgeson III, and M.S. Krishnan (2006), "Customer Satisfaction and Stock Prices:
High Returns, Low Risk,' Journal of Marketing, 70 (January), 3-14.

Fosfuri, Amdrea and Marco S. Giarratana (2009), "Masters of War: Rival's Product Innovation and New Advertising in Mature Product Markets," Management Science, 55 (2), 181-91.

Frieder, Laura and Avanidhar Subrahmanyam (2005), "Brand Perceptions and Market for Common Stock," Journal of Financial and Quantitative Analysis, 40 (1), 57-86.

Gifford, Dun, Jr. (1997), "The Value of Going Green," Harvard Business Review, 75 (5), 11-12.

Goldman, Kevin (1993), "Reebok Signs Up Newest Star in Basketball for \$15 Million,” The Wall Street Journal, (January 6), 8.

Hanssens, Dominique M., Leonard J. Parsons, and Randall L. Schultz (2001), Market Response Models, 2d ed. Boston: Kluwer Academic Publishers.

Heath, Chip and Amos Tversky (1990), "Presence and Belief: Ambiguity and Competence in Choice Under Uncertainty," in Contemporary Issues in Decision Making, K. Borcherding and O. Larichev, eds. Amsterdam: North Holland, 93-123.

Horsky, Dan and Patrick Swyngedouw (1987), "Does It Pay to Change Your Company Name? A Stock Market Perspective," Marketing Science, 6 (4), 320-25.

Huberman, Gur (2001), "Familiarity Breeds Investment," The Review of Financial Studies, 14 (3), 659-80.

Ittner, Christopher D. and David F. Larcker (1998), "Are NonFinancial Measures Leading Indicators of Financial Performance? An Analysis of Customer Satisfaction," Journal of Accounting Research, 36 (Supplement), 1-35.

Jacobson, Robert and Natalie Mizik (2009), "The Financial Markets and Customer Satisfaction: Reexamining Possible Financial Market Mispricing of Customer Satisfaction," Marketing Science, 28 (5), 810-19.

Joshi, Amit M. (2005), "The Direct, Indirect and Feedback Effects of Marketing Actions," doctoral dissertation, Anderson School of Management, University of California, Los Angeles.

and Dominique M. Hanssens (2009), "Movie Advertising and the Stock Market Valuation of Studios: A Case of 'Great Expectations'?" Marketing Science, 28 (2), 239-50.

Kothari, S.P. (2001), "Capital Markets Research in Accounting," Journal of Accounting and Business, 31 (1-3), 105-231.

Lamdin, Douglas J. (1999), "Event Studies of Regulation and New Results on the Effect of the Cigarette Advertising Ban," Journal of Regulatory Economics, 16 (2), 187-201.

Lane, Vicki and Robert Jacobson (1995), "Stock Market Reactions to Brand Extension Announcements: The Effects of Brand Attitude and Familiarity," Journal of Marketing, 59 (January), 63-77.

Lipman, Joanne (1991), "New Reebok Ads Enrage Rival by Taunting Nike's Star Endorsers," The Wall Street Journal, (February 6), 6 .

Lodish, Leonard M., Magid M. Abraham, Jeanne Livelsberger, Beth Lubetkin, Bruce Richardson, and Mary Ellen Stevens (1995), "A Summary of Fifty-Five In-Market Experimental Estimates of the Long-Term Effects of TV Advertising," Marketing Science, 14 (3), G133-40.

and Carl F. Mela (2007), "If Brands Are Built over Years, Why Are They Managed over Quarters?" Harvard Business Review, 85 (July-August), 104-112.

Luo, Xueming (2009), "Quantifying the Long-Term Impact of Negative Word of Mouth on Cash Flows and Stock Prices," Marketing Science, 28 (1), 148-65.

Mathur, Lynette Knowles and Ike Mathur (2000), "An Analysis of the Wealth Effects of Green Marketing Strategies," Journal of Business Research, 50 (November), 193-200. 
and Nanda Rangan (1997), "The Wealth Effects Associated with a Celebrity Endorser: The Michael Jordan Phenomenon," Journal of Advertising Research, 37 (May), 67-73.

Merton, Robert J. (1987), "A Simple Model of Capital Market Equilibrium with Incomplete Information," Journal of Finance, 42 (3), 483-510.

Mizik, Natalie and Robert Jacobson (2003), "Trading Off Between Value Creation and Value Appropriation: The Financial Implications of Shifts in Strategic Emphasis," Journal of Marketing, 67 (January), 63-76.

Nijs, Vincent R., Marnik G. Dekimpe, Jan-Benedict E.M. Steenkamp, and Dominique M. Hanssens (2001), "The Category-Demand Effects of Price Promotions," Marketing Science, 20 (1), 1-22.

-, Shuba Srinivasan, and Koen Pauwels (2007), "Retail Price Drivers and Retailer Profits," Marketing Science, 26 (4), 473-87.

Pauwels, Koen and Dominique M. Hanssens (2007), "Performance Regimes and Marketing Policy Shifts," Marketing Science, 26 (3), 296-311.

, Jorge Silva-Risso, Shuba Srinivasan, and Dominique M. Hanssens (2004), "New Products, Sales Promotion, and Firm Value: The Case of the Automobile Industry," Journal of Marketing, 68 (October), 142-56.
Perron, Pierre (1990), "Testing for a Unit Root in a Time Series with a Changing Mean," Journal of Business and Economic Statistics, 8 (2), 153-62.

Pope, Kyle (1992), "PC Marketers Punch Up Combative Ads," The Wall Street Journal, (October 21), 1.

Rao, Vithala R., Manoj K. Agarwal, and Denise Dahlhoff (2004), "How Is Manifest Branding Strategy Related to the Intangible Value if a Corporation?" Journal of Marketing, 68 (October), $126-41$.

Simester, Duncan, Yu (Jeffrey) Hu, Eric Brynjolfsson, and Eric T. Anderson (2009), "Dynamics of Retail Advertising: Evidence from a Field Experiment," Economic Inquiry, 47 (3), 482-99.

Simon, Carol J. and Mary W. Sullivan (1993), "The Measurement and Determinants of Brand Equity: A Financial Approach," Marketing Science, 12 (1), 28-52.

Simpson, Ana V. (2008), "Voluntary Disclosure of Advertising Expenditures," Journal of Accounting, Auditing and Finance, 23 (3), 404-436.

Sood, Ashish and Gerard J. Tellis (2009), "Do Innovations Really Payoff? Total Stock Market Returns to Innovation," Marketing Science, 28 (3), 442-56.

Srinivasan, Shuba, Koen Pauwels, Jorge Silva-Risso, and Dominique M. Hanssens (2009), "Product Innovations, Advertising, and Stock Returns," Journal of Marketing, 73 (January), 24-43. 